\footnotetext{
${ }^{1}$ Department of Animal Genetics, University of Warmia and Mazury in Olsztyn, Poland

${ }^{2}$ National Veterinary Research Institute, Department of Hygiene of Foods of Animal Origin, Puławy, Poland
}

\title{
Effects of Transferrin (TF) Polymorphism on the Levels of Some Blood Serum Indices in Clinically Healthy Piglets and Piglets with Diarrhoea Caused by Escherichia coli
}

\begin{abstract}
The effect of transferrin (TF) polymorphism and the levels of some blood serum indices, functionally linked to this protein, were studied. The following determinations were made in the blood serum of 311 hybrid suckling piglets - TF polymorphism, TIBC (total iron binding capacity), TF iron saturation percentage and levels of iron ceruloplasmin (CP) and copper.

Clinically healthy piglets and piglets with diarrhoea caused by E. coli were divided into younger (aged 10 to 14 days) and older (aged 15 to 28 days). The piglets showed two genotypes, TF AB and TF BB. The TF BB genotype dominated among clinically healthy piglets, and the TF AB genotype in those suffering from diarrhoea. TF polymorphism differentiated the levels of CP and copper in clinically healthy piglets, and modified iron concentration and TF iron saturation percentage in piglets with diarrhoea. Regardless of health status, age had an almost identical effect on the levels of blood serum indices in piglets of both genotypes.

The differences in the levels of CP, iron, and TF iron saturation percentage in healthy piglets and piglets with diarrhoea were modified by the presence of the $\mathrm{TF}^{\mathrm{A}}$ allele, but in older piglets only.
\end{abstract}

Key Words: polymorphism, transferrin, diarrhoea, E. coli, piglets, ceruloplasmin, iron, total iron binding capacity, copper, serum.

\section{Zusammenfassung}

Titel der Arbeit: Einfluss des Transferrinpolymorphismus (TF) auf das Niveau einiger Blutserumindikatoren bei klinisch gesunden und an Durchfall (Escherichia coli) erkrankten Ferkeln

Es wurde der Einfluss von Transferrinpolymorphismus (TF) auf das Niveau von Blutserumindikatoren untersucht, die funktionell mit diesem Eiweiß verbunden sind. Bestimmt wurden: Der Transferrinpolymorphismus, der Eisenspiegel, TEBK, der Saturationsprozentsatz von TF mit Eisen, der Gehalt von Ceruloplasmin (CP) und der des Kupfers im Blutserum bei 311 Saugferkeln.

Die klinisch gesunden und die an Durchfall erkrankten Ferkel wurden in Bezug auf E. coli in zwei Gruppen aufgeteilt, in jüngere (vom 10. bis zum 14. Lebenstag) und in ältere (vom 15. bis zum 28. Lebenstag). Es wurde die Anwesenheit von Genotypen TF AB und TF BB festgestellt. Bei den gesunden Ferkeln war am meisten der Genotyp TF BB vertreten und bei den unter Durchfall leidenden Ferkeln der Genotyp TF AB.

Der Transferrinpolymorphismus (TF) differenzierte das Niveau von CP und Kupfer im Blutserum der gesunden Ferkel, bei den kranken Ferkeln dagegen modifizierte er das Eisenniveau und den Prozentsatz der TF-Saturation mit Eisen.

Unabhängig vom Gesundheitszustand der untersuchten Ferkel, beeinflusste das Alter das Niveau der zu bestimmenden Parameter bei beiden Genotypen.

Der differenzierte Eisenspiegel, der Prozentsatz der TF-Saturation mit Eisen und das Niveau von CP wurde zwischen den gesunden und kranken Ferkeln durch die Anwesenheit vom Allel TFA modifiziert, dies aber ausschließlich bei älteren Ferkeln.

Schlüsselwörter: Polymorphismus, Transferrin, Durchfall, E. coli, Ferkel, Ceruloplasmin, Eisen, totale Eisenbindungskapazität, Kupfer, Blutserum

\section{Introduction}

Transferrin (TF) is a serum glycoprotein that binds free iron ions. In farm animals (including pigs) transferrin shows genetically determined polymorphism, which 
manifests itself by the occurrence of numerous transferrin variants within a population, differing in structure. Their presence (determined in pigs by nine alleles inherited through codominance) is a consequence of point mutations within the TF-encoding gene (VEDRINE et al., 1996; JUNEJA and VÖGELI, 1998).

The $\mathrm{TF}^{\mathrm{A}}$ and $\mathrm{TF}^{\mathrm{B}}$ allele variants are the most common among European pig breeds (JUNEJA and VÖGELI, 1998). In piglets their presence modifies the expression of some quantitative traits. The occurrence of the $\mathrm{TF}^{\mathrm{B}}$ allele (as compared with the $\mathrm{TF}^{\mathrm{A}}$ allele) is related to an increase in the body weights of piglets (NYSTRÖM et al., 1997), as well as the acceleration of their growth rate (KRIŻOVA et al., 2000). This suggests that the presence of the $\mathrm{TF}^{\mathrm{B}}$ allele is more desirable than the presence of the $\mathrm{TF}^{\mathrm{A}}$ allele in piglets, which is also confirmed by the effects of these alleles on their health status. Carriers of the $\mathrm{TF}^{\mathrm{B}}$ allele less frequently suffer from diarrhoea caused by strains of Escherichia coli (E. coli) bacteria that have K88 antigens (renamed F4) than carriers of the $\mathrm{TF}^{\mathrm{A}}$ allele (GIBBONS et al., 1977; BONNEAU et al., 1990; $\dot{Z} Y C Z K O$ and ŻYCZKO, 1999). This correlation is believed to result from linkage of the TF and loci F4abR and F4acR on SSC 13. The distance between the loci Tf and F4abR is $7.4 \mathrm{cM}$, whereas between the loci F4abR and F4acR - about $1.0 \mathrm{cM}$ (EDFORS-LILJA et al., 1995). NYSTRÖM et al. (1997) are of a different opinion. According to these authors, the more beneficial effect of the $\mathrm{TF}^{\mathrm{B}}$ allele, as compared with $\mathrm{TF}^{\mathrm{A}}$, may also result from the differentiated participation of polymorphic $\mathrm{TF}$ variants in biological functions. It seems that this problem requires further investigations, since authors (VORON et al., 1974; PRZYTULSKI et al., 1981) vary in their opinions on the different levels of the iron-binding ability revealed by polymorphic TF variants in pigs. Transferrin shows bacteriostatic activity, which is part of non-specific (innate) defence mechanisms (HUEBERS and FINCH, 1987; de JONG et al, 1990). In performing this function transferrin is supported by ceruloplasmin (CP) - a copper-binding serum glycoprotein (YOUNG et al., 1997; BIGOSZEWSKI et al., 2001). It remains unknown whether the combined effects of these proteins observed in non-specific defence processes are modified by TF polymorphism. Their interaction has not been studied so far in the context of piglet susceptibility/resistance to diarrhoea caused by E. coli; neither has been the linkage between TF and CP loci on SSC 13 (EDFORS-LILJA et al., 1995). Until quite recently the relationship between transferrin and piglet susceptibility/resistance to diarrhoea caused by E. coli F4 was perceived exclusively from the perspective of the linkage disequilibrium between TF and loci F4abR and F4acR (EDFORS-LILJA et al., 1995), as well as the analogy of structures of transferrin and receptors for adhesions of E. coli F4ab, found on small intestinal enterocytes (GRANGE and MOURICOUT, 1996).

The aim of the present study was to analyse the potential relationship between transferrin polymorphism and the levels of some blood serum indices, functionally linked to this protein, in clinically healthy piglets and piglets with diarrhoea caused by E.coli bacteria.

\section{Materials and Methods}

A total of 311 suckling piglets aged 10 to 14 days (a younger group) and 15 to 28 days (an older group), produced by crossing Polish Landrace sows $(\mathrm{n}=112$ ) with Polish Large White, Duroc, Duroc x Pietrain boars, were examined. Some of the sibs were 
clinically healthy $(\mathrm{n}=166)$, while others, selected randomly, showed symptoms of diarrhoea $(n=145)$. Faeces samples $(n=145)$ were collected from piglets with diarrhoea to perform bacteriological tests (at specialist laboratories) for the presence of E. coli strains. E. coli strains were divided into haemolytic $(\mathrm{H})$ and non-haemolytic (N) - and fimbrial antigens F4ab and F4ac were identified by the method developed by OSEK and TRUSZCZYŃSKI (1992).

The following determinations were made in the blood serum of the piglets $(n=311$ samples): TF polymorphism - by horizontal starch gel electrophoresis, as described by HESSELHOLT (1969), levels of: TIBC (total iron binding capacity) and total iron $\mathrm{Fe}^{2+}(\mathrm{n}=311$ samples) - following the instructions on the package of Biochemtest reagents purchased from POCH Gliwice (catalogue number 178303149), TF iron saturation - from the formula: $\left(\mathrm{Fe}^{2+} \mu \mathrm{mol} / \mathrm{L}\right.$ : TIBC $\left.\mu \mathrm{mol} / \mathrm{L}\right)$ x $100 \%$, ceruloplasmin concentration - by the Houchin method (as cited in SZCZEKLIK, 1974), and copper by atomic absorption, using a UNICAM 939W densitometer. Due to the lack of blood serum, CP and copper were determined on 293 samples only.

The data are presented as arithmetic means (x) and standard deviations (s). Prior to statistical analysis the values of iron content and TF iron saturation percentage were transformed logarithmically. These calculations are not shown since they corresponded to the non-transformed results.

The following statistical methods were applied:

1. $\mathrm{Chi}^{2}$ test - to compare the frequencies of $\mathrm{TF}$ alleles and genotypes in animals differing in health status (clinically healthy piglets and piglets with diarrhoea caused by E. coli strains) and in age (younger and older piglets).

2. A two-factorial analysis of variance in a non-orthogonal design and the $\mathrm{F}$ (Fisher) test - to compare the effect of TF polymorphism (AB and $\mathrm{BB}$ genotypes) and age (younger and older piglets) on the levels of blood serum indices, separately for clinically healthy piglets and piglets with diarrhoea, as well as to verify the effect of TF polymorphism on the defence response against E. coli. In order to do that, the levels of blood serum indices were compared in animals differing in health status (clinically healthy piglets and piglets with diarrhoea caused by E. coli strains) and in age (younger and older piglets), analyzing the defence effect separately in TF $\mathrm{AB}$ and TF $\mathrm{BB}$ piglets (the results are shown in Tables 3 and 4). The calculation were made using STATISTICA 6.0 PL software.

\section{Results}

General characteristics of the piglets are given in Table 1.

The piglets showed two genotypes, TF AB $(n=166)$ and TF BB $(n=145)$. The frequency of $\mathrm{TF} \mathrm{AB}$ and $\mathrm{TF} \mathrm{BB}$ was $53.38 \%$ and $46.62 \%$ respectively (the total number of piglets being $n=311)$. Among clinically healthy piglets $(n=166)$ TF AB and TF BB genotypes accounted for $44.58 \%$ and $55.42 \%$ respectively, whereas among piglets with diarrhoea - for $63.44 \%$ and $36.56 \%$ respectively.

In the faeces samples collected from piglets with diarrhoea, non-haemolytic $(\mathrm{N})$ and haemolytic (H) E. coli strains constituted $76.55 \%$ and $23.46 \%$ respectively. Strains without (F4) and with F4 antigens constituted $73.10 \%$ and $26.90 \%$ respectively. 
Arch. Tierz. 49 (2006) 5

Table 1

Characteristics of the experimental materials (Charakteristik des untersuchten Materials)

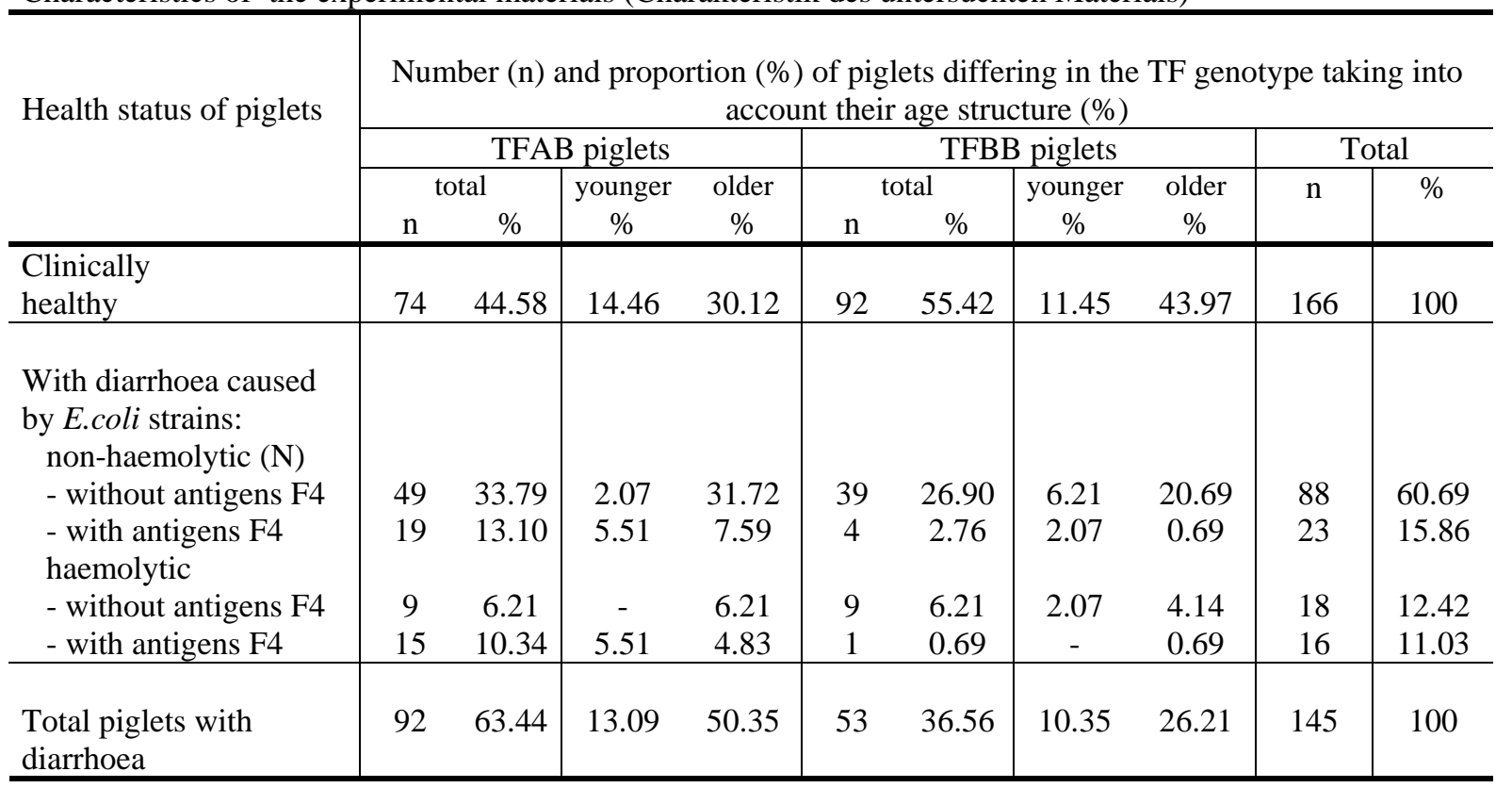

Table 2

Influence of $\mathrm{TF}$ genotypes on the health status of piglets at different age (Einfluss des Transferringenotyps auf den Gesundheitszustand von Ferkeln unterschiedlichen Alters)

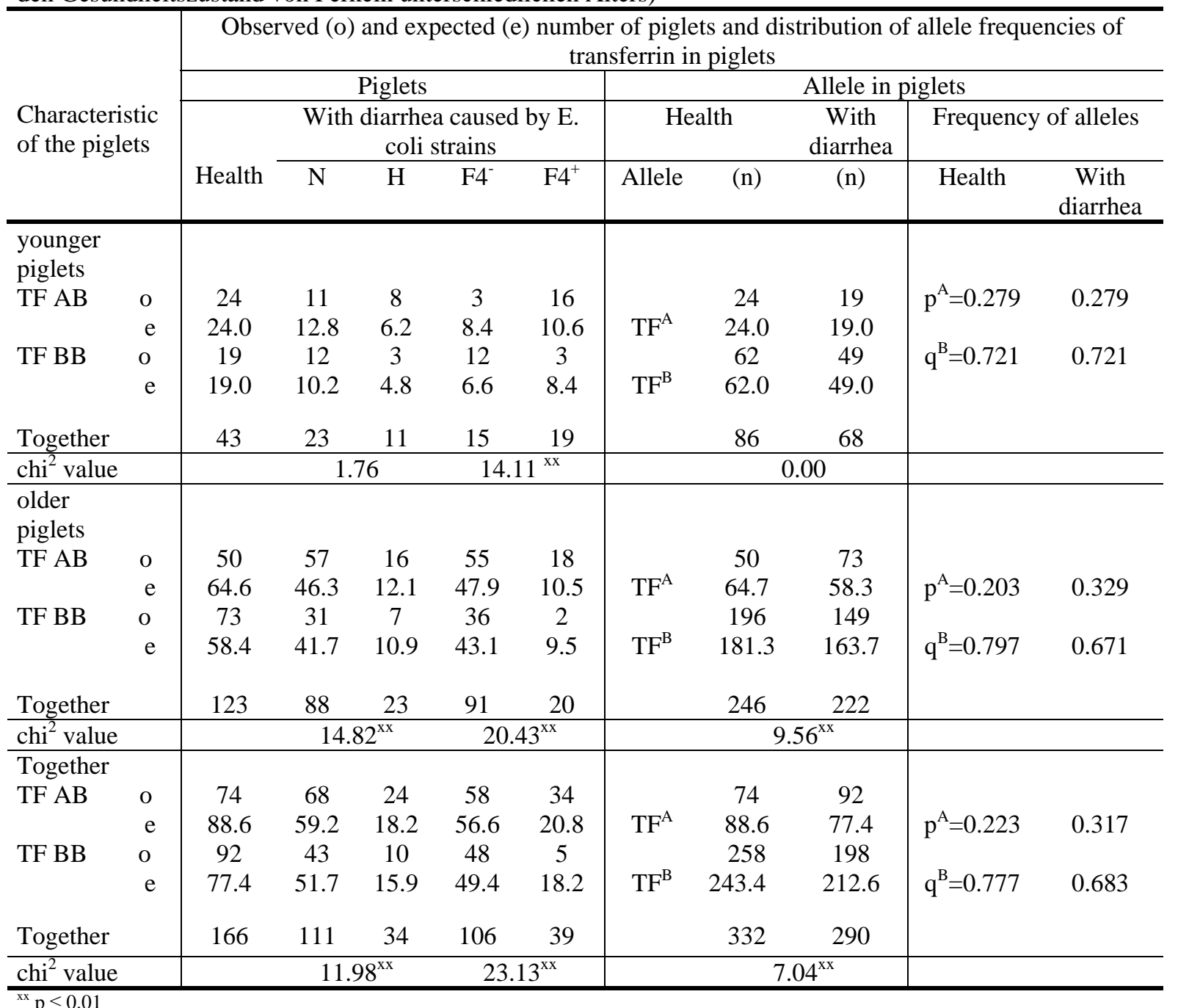


The correlation between TF polymorphism and the health state of piglets is presented in Table 2.

Among healthy piglets the number of TF BB genotypes was higher, and the number of TF AB genotypes was lower than expected. Among piglets with diarrhoea caused by $\mathrm{N}$ and $\mathrm{H} E$. coli strains the number of TF $\mathrm{AB}$ genotypes was higher, and the number of TF BB genotypes was lower than expected. Deviations between the observed and expected number were recorded in older piglets only. Irrespective of age, the observed number of TF AB piglets with diarrhoea caused by E. coli strains with F4 antigens ( $\mathrm{F}^{+}$) was higher than expected. The deviations between the actual and expected number were less significant in piglets with diarrhoea caused by E. coli strains without $\mathrm{F} 4$ antigens $\left(\mathrm{F} 4^{-}\right)$. A lower frequency of the $\mathrm{TF}^{\mathrm{A}}$ gene $\left(\mathrm{p}^{\mathrm{A}}=0.223\right)$ and a higher frequency of the $\mathrm{TF}^{\mathrm{B}}$ gene $\left(\mathrm{q}^{\mathrm{B}}=0.777\right)$ were recorded in clinically healthy piglets, in comparison with those suffering from diarrhoea $\left(\mathrm{p}^{\mathrm{A}}=0.317, \mathrm{q}^{\mathrm{B}}=0.683\right)$.

Since in previous studies (ŻYCZKO and ŻYCZKO, 2005) no differences were observed in the effects of the above $E$. coli strains ( $\mathrm{N}$ and $\mathrm{H}, \mathrm{F}^{+}$and $\mathrm{F} 4{ }^{-}$) on the levels of blood serum indices, they were treated as one group.

The relationship between TF polymorphism and the levels of blood serum parameters is shown in Table 3.

Table 3

Relationship between transferrin polymorphism and the levels of some blood serum indices in clinically healthy piglets differing in age (Zusammenhang zwischen Transferrinpolymorphismus und dem Niveau der untersuchten Blutserumindikatoren bei gesunden Ferkeln unterschiedlichen Alters)

\begin{tabular}{|c|c|c|c|c|c|c|c|c|c|c|c|c|c|}
\hline \multirow[t]{3}{*}{ Indices } & \multirow{3}{*}{$\begin{array}{c}\text { Genotype } \\
\text { TF }\end{array}$} & \multicolumn{9}{|c|}{ Age of piglets } & \multicolumn{3}{|c|}{ Sources of variation } \\
\hline & & \multicolumn{3}{|c|}{ younger } & \multicolumn{3}{|c|}{ older } & \multicolumn{3}{|c|}{ total } & & & \\
\hline & & $\mathrm{n}$ & $\overline{\mathrm{X}}$ & $\mathrm{S}$ & $\mathrm{n}$ & $\bar{x}$ & $\mathrm{~S}$ & $\mathrm{n}$ & $\overline{\mathrm{X}}$ & $\mathrm{S}$ & G & A & $\mathrm{G} \times \mathrm{A}$ \\
\hline $\begin{array}{l}\text { Iron } \\
\mu \mathrm{mol} / \mathrm{l}\end{array}$ & $\begin{array}{c}\mathrm{AB} \\
\mathrm{BB} \\
\text { total }\end{array}$ & $\begin{array}{l}24 \\
19 \\
43\end{array}$ & $\begin{array}{l}10.29 \\
14.95 \\
12.34\end{array}$ & $\begin{array}{c}6.892 \\
10.259 \\
8.852\end{array}$ & $\begin{array}{c}50 \\
73 \\
123\end{array}$ & $\begin{array}{l}20.95 \\
20.52 \\
20.71\end{array}$ & $\begin{array}{c}10.181 \\
9.484 \\
9.776\end{array}$ & $\begin{array}{c}74 \\
92 \\
166\end{array}$ & $\begin{array}{l}17.50 \\
19.37 \\
18.53\end{array}$ & $\begin{array}{c}10.505 \\
9.911 \\
10.223\end{array}$ & ns & $\mathrm{XX}$ & ns \\
\hline $\begin{array}{l}\text { TIBC } \\
\mu \mathrm{mol} / \mathrm{l}\end{array}$ & $\begin{array}{c}\mathrm{AB} \\
\mathrm{BB} \\
\text { total }\end{array}$ & $\begin{array}{l}24 \\
19 \\
43\end{array}$ & $\begin{array}{l}113.79 \\
108.04 \\
111.25\end{array}$ & $\begin{array}{l}18.461 \\
25.661 \\
22.121\end{array}$ & $\begin{array}{c}50 \\
73 \\
123\end{array}$ & $\begin{array}{c}96.46 \\
104.07 \\
100.98\end{array}$ & $\begin{array}{l}27.930 \\
30.363 \\
29.635\end{array}$ & \begin{tabular}{|c}
74 \\
92 \\
166
\end{tabular} & $\begin{array}{l}102.08 \\
104.89 \\
103.64\end{array}$ & $\begin{array}{l}26.523 \\
29.497 \\
28.245\end{array}$ & ns & $\mathrm{x}$ & ns \\
\hline $\begin{array}{l}\text { TF iron } \\
\text { saturation } \\
\%\end{array}$ & $\begin{array}{c}\mathrm{AB} \\
\mathrm{BB} \\
\text { total }\end{array}$ & $\begin{array}{l}24 \\
19 \\
43\end{array}$ & $\begin{array}{c}9.00 \\
14.96 \\
11.63\end{array}$ & $\begin{array}{l}5.108 \\
8.614 \\
7.489\end{array}$ & $\begin{array}{c}50 \\
73 \\
123\end{array}$ & $\begin{array}{l}24.00 \\
21.71 \\
22.64\end{array}$ & $\begin{array}{l}13.535 \\
10.749 \\
12.013\end{array}$ & \begin{tabular}{|c}
74 \\
92 \\
166
\end{tabular} & $\begin{array}{l}19.14 \\
20.32 \\
19.79\end{array}$ & $\begin{array}{l}13.472 \\
10.700 \\
12.030\end{array}$ & ns & $\mathrm{XX}$ & $\mathrm{x}$ \\
\hline $\begin{array}{l}\text { Cerulo- } \\
\text { plasmin } \\
\text { mg/100ml }\end{array}$ & $\begin{array}{c}\mathrm{AB} \\
\mathrm{BB} \\
\text { total }\end{array}$ & $\begin{array}{l}20 \\
20 \\
40\end{array}$ & $\begin{array}{l}16.31 \\
12.89 \\
14.61\end{array}$ & $\begin{array}{l}4.538 \\
3.314 \\
4.288\end{array}$ & $\begin{array}{c}51 \\
67 \\
118\end{array}$ & $\begin{array}{l}29.17 \\
23.77 \\
26.07\end{array}$ & $\begin{array}{l}9.902 \\
6.523 \\
8.560\end{array}$ & $\begin{array}{c}71 \\
87 \\
158\end{array}$ & $\begin{array}{l}25.55 \\
21.23 \\
23.17\end{array}$ & $\begin{array}{c}10.467 \\
7.489 \\
9.177\end{array}$ & $\mathrm{xx}$ & $\mathrm{XX}$ & ns \\
\hline $\begin{array}{l}\text { Copper } \\
\mu \mathrm{mol} / \mathrm{l}\end{array}$ & $\begin{array}{c}\mathrm{AB} \\
\mathrm{BB} \\
\text { total } \\
\end{array}$ & $\begin{array}{l}20 \\
20 \\
40 \\
\end{array}$ & $\begin{array}{l}31.38 \\
29.98 \\
30.67\end{array}$ & $\begin{array}{l}7.603 \\
7.218 \\
7.355\end{array}$ & $\begin{array}{c}51 \\
67 \\
118\end{array}$ & $\begin{array}{l}33.69 \\
27.84 \\
30.37\end{array}$ & $\begin{array}{l}9.884 \\
5.716 \\
8.288\end{array}$ & \begin{tabular}{|c}
71 \\
87 \\
158 \\
\end{tabular} & $\begin{array}{l}33.05 \\
28.33 \\
30.45\end{array}$ & $\begin{array}{l}9.306 \\
6.116 \\
8.039 \\
\end{array}$ & $\mathrm{xx}$ & ns & ns \\
\hline
\end{tabular}


In clinically healthy piglets TF polymorphism differentiated only the levels of $\mathrm{CP}$ and copper. TF AB piglets showed their higher concentrations than TF BB piglets $(\mathrm{p} \leq 0.01)$. The interaction genotype $\mathrm{x}$ age $(\mathrm{p} \leq 0.05)$ affected TF iron saturation percentage. The level of this index was much lower in younger TF $\mathrm{AB}$ piglets and slightly higher in older $\mathrm{TF} \mathrm{AB}$ piglets, as compared with $\mathrm{TF} \mathrm{BB}$ ones. In healthy piglets age modified the levels of all blood serum indices except copper. Older piglets, compared with younger ones, had a higher iron concentration ( $\mathrm{p} \leq 0.01)$, a lower TIBC $(\mathrm{p} \leq 0.05)$ and a higher CP level $(\mathrm{p} \leq$ 0.01 ). The differences in the levels of the first three parameters were more noticeable in the TF AB genotype than in the TF BB genotype.

Transferrin polymorphism in piglets with diarrhoea (Table 4) affected iron concentration and TF iron saturation.

Table 4

Relationship between transferrin polymorphism and the levels of some blood serum indices in piglets with diarrhoea caused by E.coli (Zusammenhang zwischen dem Transferrinpolymorphismus und dem Niveau der untersuchten Blutserumindikatoren bei den an Durchfall erkrankten Ferkeln auf Basis von E.coli)

\begin{tabular}{|c|c|c|c|c|c|c|c|c|c|c|c|c|c|}
\hline \multirow[t]{3}{*}{ Indices } & \multirow{3}{*}{$\begin{array}{c}\text { Genotype } \\
\text { TF }\end{array}$} & \multicolumn{9}{|c|}{ Age of piglets } & \multicolumn{3}{|c|}{ Sources of variation } \\
\hline & & \multicolumn{3}{|c|}{ younger } & \multicolumn{3}{|c|}{ older } & \multicolumn{3}{|c|}{ total } & & & \\
\hline & & $\mathrm{n}$ & $\bar{x}$ & $\mathrm{~s}$ & $\mathrm{n}$ & $\bar{x}$ & $\mathrm{~s}$ & $\mathrm{n}$ & $\bar{x}$ & $\mathrm{~s}$ & $\mathrm{G}$ & $\mathrm{A}$ & $\mathrm{G} \times \mathrm{A}$ \\
\hline $\begin{array}{l}\text { Iron } \\
\mu \mathrm{mol} / \mathrm{l}\end{array}$ & $\begin{array}{l}\mathrm{AB} \\
\mathrm{BB} \\
\text { total }\end{array}$ & $\begin{array}{l}19 \\
15 \\
34\end{array}$ & $\begin{array}{l}16.74 \\
19.06 \\
17.76\end{array}$ & $\begin{array}{l}11.599 \\
12.512 \\
12.066\end{array}$ & $\begin{array}{c}73 \\
38 \\
111\end{array}$ & $\begin{array}{l}16.49 \\
26.39 \\
19.88\end{array}$ & $\begin{array}{c}9.501 \\
14.037 \\
12.201\end{array}$ & $\begin{array}{c}92 \\
53 \\
145\end{array}$ & $\begin{array}{l}16.54 \\
24.32 \\
19.38\end{array}$ & $\begin{array}{c}9.971 \\
14.016 \\
12.203\end{array}$ & $x$ & ns & ns \\
\hline $\begin{array}{l}\text { TIBC } \\
\mu \mathrm{mol} / \mathrm{l}\end{array}$ & $\begin{array}{l}\mathrm{AB} \\
\mathrm{BB} \\
\text { total }\end{array}$ & $\begin{array}{l}19 \\
15 \\
34\end{array}$ & $\begin{array}{l}86.79 \\
94.73 \\
90.29\end{array}$ & $\begin{array}{l}32.056 \\
26.637 \\
30.047\end{array}$ & $\begin{array}{c}73 \\
38 \\
111\end{array}$ & $\begin{array}{l}70.27 \\
75.43 \\
72.04\end{array}$ & $\begin{array}{l}11.786 \\
19.416 \\
15.046\end{array}$ & $\begin{array}{c}92 \\
53 \\
145\end{array}$ & $\begin{array}{l}73.68 \\
80.91 \\
76.32\end{array}$ & $\begin{array}{l}24.176 \\
23.317 \\
21.091\end{array}$ & ns & $x x$ & ns \\
\hline $\begin{array}{l}\text { TF iron } \\
\text { saturation } \\
\%\end{array}$ & $\begin{array}{l}\mathrm{AB} \\
\mathrm{BB} \\
\text { total }\end{array}$ & $\begin{array}{l}19 \\
15 \\
34\end{array}$ & $\begin{array}{l}24.61 \\
22.10 \\
23.51\end{array}$ & $\begin{array}{l}20.362 \\
12.246 \\
17.303\end{array}$ & $\begin{array}{c}73 \\
38 \\
111\end{array}$ & $\begin{array}{l}26.54 \\
38.30 \\
30.57\end{array}$ & $\begin{array}{l}17.171 \\
23.463 \\
20.334\end{array}$ & $\begin{array}{c}92 \\
53 \\
145\end{array}$ & $\begin{array}{l}26.15 \\
33.71 \\
28.92\end{array}$ & $\begin{array}{l}17.894 \\
22.146 \\
19.893\end{array}$ & $\mathrm{x}$ & $\mathrm{x}$ & $\mathrm{x}$ \\
\hline $\begin{array}{l}\text { Cerulo- } \\
\text { plasmin } \\
\mathrm{mg} / 100 \mathrm{ml}\end{array}$ & $\begin{array}{c}\mathrm{AB} \\
\mathrm{BB} \\
\text { total }\end{array}$ & $\begin{array}{l}18 \\
13 \\
31\end{array}$ & $\begin{array}{l}21.38 \\
23.86 \\
22.42\end{array}$ & $\begin{array}{l}4.993 \\
4.377 \\
4.831\end{array}$ & $\begin{array}{c}69 \\
35 \\
104\end{array}$ & $\begin{array}{l}27.88 \\
30.38 \\
28.72\end{array}$ & $\begin{array}{l}8.906 \\
9.565 \\
9.163\end{array}$ & $\begin{array}{c}87 \\
48 \\
135\end{array}$ & $\begin{array}{l}26.54 \\
28.61 \\
27.28\end{array}$ & $\begin{array}{l}8.642 \\
8.924 \\
8.766\end{array}$ & ns & $x x$ & ns \\
\hline $\begin{array}{c}\text { Copper } \\
\mu \mathrm{mol} / \mathrm{l}\end{array}$ & $\begin{array}{c}\mathrm{AB} \\
\mathrm{BB} \\
\text { total }\end{array}$ & $\begin{array}{l}18 \\
13 \\
31\end{array}$ & $\begin{array}{l}31.71 \\
30.15 \\
31.07\end{array}$ & $\begin{array}{l}6.454 \\
5.090 \\
5.878\end{array}$ & $\begin{array}{c}69 \\
35 \\
104\end{array}$ & $\begin{array}{l}30.15 \\
29.38 \\
29.89\end{array}$ & $\begin{array}{l}6.393 \\
5.606 \\
6.122\end{array}$ & $\begin{array}{c}87 \\
48 \\
135\end{array}$ & $\begin{array}{l}30.48 \\
29.59 \\
30.15\end{array}$ & $\begin{array}{l}6.399 \\
5.405 \\
6.066\end{array}$ & $\mathrm{~ns}$ & ns & ns \\
\hline
\end{tabular}

$\mathrm{G}$ - genotype ; A - age; $\mathrm{G} \times \mathrm{A}$ - interaction genotype $\mathrm{x}$ age

$\mathrm{x}-\mathrm{p} \leq 0.05 ; \mathrm{xx}-\mathrm{p} \leq 0.01$

ns - non significant

A lower iron concentration was recorded in TF AB piglets, compared with TF BB piglets ( $\mathrm{p} \leq 0.05$ ). The level of TF iron saturation was modified by the interaction genotype $x$ age $(\mathrm{p} \leq 0.05)$. The value of this index was somewhat higher in younger $\mathrm{TF} \mathrm{AB}$ piglets and considerably lower in older TF AB piglets, in comparison with 
those of the TF BB genotype. It follows that TF iron saturation was lower in TF AB piglets than in TF BB ones $(\mathrm{p} \leq 0.05)$.

The effects of the TF AB and TF BB genotypes on the levels of blood serum indices in clinically healthy piglets and piglets with diarrhoea were compared in the study taking into account age differences between them. It was found that healthy piglets TF BB had a lower iron level $(p \leq 0.05)$ and a lower TF iron saturation percentage $(p \leq 0,01)$ then piglets with diarrhoea. Within the TF AB genotype these parameters were affected by the interaction between age and health state $(p \leq 0.05)$. Younger healthy TF AB piglets were characterized by a lower iron concentration and a much lower TF iron saturation than younger TF AB piglets with diarrhoea, whereas older healthy piglets of the same genotype had a higher iron level than older ones with diarrhoea.

No differences were found in the effects of the TF AB and TF BB genotypes on TIBC. Both healthy TF AB and TF BB piglets showed a higher value of this index than TF $\mathrm{AB}$ and $\mathrm{TF} \mathrm{BB}$ piglets with diarrhoea $(\mathrm{p} \leq 0.01)$.

The TF $\mathrm{AB}$ and TF $\mathrm{BB}$ had differentiated effects on $\mathrm{CP}$ level. A lower $\mathrm{CP}$ concentration was observed in the blood serum of healthy TF BB piglets (regardless of age), as compared with TF BB piglets suffering from diarrhoea $(\mathrm{p} \leq 0.01)$. Such a relationship was also found between younger $\mathrm{TF} A B$ piglets, healthy and with diarrhoea, while no differences in CP level were recorded between older piglets (age $\mathrm{x}$ health status interaction, $\mathrm{p} \leq 0.05$ ). The level of copper was similar in both genotypes, irrespective of health status and age.

\section{Discussion}

The health state of piglets is determined, to a great extent, by non-specific (innate), immunity. The system of nutritional immunity, based upon proteins that bind iron in the blood serum (transferrin) and in body fluids and secretions (lactoferrin), plays and important role in non-specific defence mechanisms. These proteins make iron unavailable to pathogens, thus inhibiting their proliferation. The defence ability of transferrin is reflected by the values of two indices, i.e. TIBC and TF iron saturation. In clinically healthy piglets transferrin polymorphism affected neither the levels of these indices nor iron concentration (Table 3), which was also reported for porkers (PRZYTULSKI et al., 1981) and sows (ŻYCZKO and ŻYCZKO, 2000). On the other hand, the type of TF affected the levels of Cp and copper, which were found to be higher in piglets of the TF AB genotype than in those of the TF BB genotype (Table 3). According to PRZYTULSKI et al. (1981), the highest values of these indices were recorded in TF AA porkers, lower in TF AB porkers, and the lowest in TF BB ones. The reasons for such a relationship, observed also in sows (ŻYCZKO and $\dot{Z} Y C Z K O$, 2000), remain unknown. The effect of the $\mathrm{TF}^{\mathrm{A}}$ allele on an increase in serum copper cannot be excluded, since it was found in sheep (BARANOWSKI and KMIEĆ, 1997). The constantly elevated CP level in piglets of the TF AB genotype, as compared with those of the TF BB genotype, may indicate chronic stimulation of the defence system, as suggested by KOSTRO et al. (2001). The acute phase response (activated at the early stage of infection) involves a series of reactions, aimed at controlling the inflammatory focus, and inactivating pathogens and their products in order to restore homeostasis (BIGOSZEWSKI et al., 2001; KOSTRO et al., 2001). They influence numerous metabolic processes, causing changes in the concentrations of some serum proteins, called acute phase proteins. Proteins that respond by an increase in serum 
concentrations are referred to as positive, whereas those whose serum concentrations decrease - as negative (BIGOSZEWSKI et al., 2001; KOSTRO et al., 2001). Despite certain physicochemical and functional differences, these two groups of proteins cooperate. For instance, both ceruloplasmin and transferrin participate in enhancing and modulating defence processes (BIGOSZEWSKI et al., 2001; KOSTRO et al., 2001).

Ceruloplasmin is a second-line, slow-reacting positive protein (ECKERSALL et al., 1996; BIGOSZEWSKI et al., 2001). In pigs CP concentration increases on the second day following turpentine injection, to reach the maximum value on the fourth day of infection (ECKERSALL et al., 1996). Despite this, ceruloplasmin is considered a sensitive indicator of inflammatory processes, reflecting the intensification of adaptive responses (WIECZOREK, 2003). Ceruloplasmin contributes also to chemotaxis enhancement (SAENKO et al., 1994), as well as to the elimination and degradation of excessive free oxygen radicals, formed as a result of stimulated defence responses (KIM et al., 1998).

Transferrin belongs to negative acute phase proteins (LAMPREAVE et al., 1994; KOSTRO et al., 2001). Together with other defence mechanisms, it contributes to hypoferremia, i.e. a decrease in serum iron ( HUEBERS and FINCH, 1987; de JONG et al., 1990), aimed at making iron unavailable to pathogens and preventing iron participation in generating hydroxyl radicals (WIELEBA and PASTERNAK, 2001). The initiation, duration and severity of hypoferremia depend, among others, on the intensity of inflammation (HUEBERS and FINCH, 1987), and on genetic factors (ZAGULSKI, 1992). The inhibitory effect of TF on pathogens weakens along with an increase in its saturation with iron (HUEBERS and FINCH, 1987; de JONG et al.,1990).

TF iron saturation was slightly higher in younger TF AB piglets with diarrhoea, compared with TF BB piglets, which was considered an indication of their weaker defence response related, among others, to latent iron deficiency. This is confirmed by the results concerning iron concentration, TIBC, TF iron saturation percentage obtained in younger healthy piglets of the TF AB genotype (Table 3). Such a tendency was also reported by ZDUNCZYK et al. (1993). A lower iron level in TF AB piglets with diarrhoea, in comparison with TF BB piglets, is considered to be a defence effect that manifests itself by changes in iron metabolism, linked (through CP) to copper metabolism. The above results could be also affected by the specificity of the TF AB genotype, reflected by elevated levels of $\mathrm{CP}$ and copper, in relation to the TF $\mathrm{BB}$ genotype (Table 3).

Differentiated effects of the TF AB and TF BB genotypes on the levels of CP and iron, and $\mathrm{TF}$ iron saturation percentage in clinically healthy piglets and piglets with diarrhoea was observed in the older group only (piglets aged 15 to 28 days). This suggests the existence of a relationship between the differentiated defence response in piglets of the TF AB and TF BB genotypes and the stage of their life at which their general immunity is usually lower due to, among others, hypogammaglobulinaemia (KRAKOWSKI et al., 1998), often accompanied by iron deficiency. These factors predispose piglets to infections, including those caused by E. coli (KRAKOWSKI et al., 1998).

It may be concluded that transferrin polymorphism which manifested itself by the occurrence of $\mathrm{TF}^{\mathrm{A}}$ and $\mathrm{TF}^{\mathrm{B}}$ alleles affected the levels of blood serum indices in 
clinically healthy piglets and piglets with diarrhoea caused by E. coli. The presence of the $\mathrm{TF}^{\mathrm{A}}$ allele resulted in elevated levels of ceruloplasmin and copper in healthy piglets, and reduced iron concentration and TF iron saturation percentage in piglets with diarrhoea. The differences in the levels of CP, iron, and TF iron saturation percentage in healthy piglets and piglets with diarrhoea were modified by the presence of the $\mathrm{TF}^{\mathrm{A}}$ allele, but in older piglets only.

\section{References \\ BARANOWSKI, P.; KMIEĆ, M.:} Haematological and blood chemical indices in Polish Longhaired sheep (in Polish). Życie Wet., 72 (1997) 9, 355-357

BIGOSZEWSKI, M.; RYCHLIK, A.; DEPTA, A.:

Acute phase proteins in domestic animals ( in Polish ). Medycyna Wet., 53 (2001) 3, 151-155

BONNEAU, M.; DUVAL-IFLAH, Y.; GUERIN G.; OLLIVIER, L.; RENARD, C.; RENJIFO, X.:

Aspects gènètiques et microbiologiques de la colibacillose K88 chez le porc. Ann. Rech. Vet., 21 (1990), 302-303

ECKERSALL, P.D.; SAINI, P.K.; Mc COMB, C.:

The acute phase response of acid soluble glycoprotein, alpha-1 glycoprotein, ceruloplasmin, haptoglobin and C-reactive protein, in the pig. Vet. Immunol. Immunopath, 51 (1996), 377-385

EDFORS-LILJA, I.; GUSTAFSSON, U.; DUVAL-IFLAH, Y.; ELLEGREN, H.; JOHANSSON, M.; JUNEJA,

R.K.; MARKLUND, L.; ANDERSSON, L.:

The porcine intestinal receptor for Escherichia coli K88ab, K88ac: regional localization on chromosome 13 and influence of IgG response to the K88 antigen. Anim. Genet., 26 (1995), 237-242

GIBBONS, R.A.; SELLWOOD, R.; BURROWS, M.; HUNTER, P.A.:

Inheritance of resistance to neonatal E.coli diarrhoea in the pig: examination of the genetic system. Theor. Appl. Genet., 51 (1977), 65-70

GRANGE, P.A.; MOURICOUT, M.A.:

Transferrin associated with the porcine intestinal mucosa. Is a receptor specific for K88ab fimbriae of Escherichia coli. Infect. Immun., 64 (1996) 2, 606-610

HESSELHOLT, M.:

Serum protein polymorphism in swine. Electrophoretic identification. Genetic and application. Muskagaard. Kopenhagen (1969), 35-38

HUEBERS, H.A.; FINCH, C.A.: The physiology of transferrin and transferrin receptors. Phys. Rev., 67 (1987) 2, 520-565

DE JONG, G.; DIJK, J.P.; VAN EIJK, H.G.:

The biology of transferrin. Clin. Chim. Acta, 190 (1990), 1-46

JUNEJA, R.K.; VÖGELI, P.:

The genetic of the pigs. Editor ROTHSCHILD M.F., RUVINSKY A.: Biochemical Genetics (1998), 105-125

KIM, I.G.; PARK, S.Y.; KIM, K.C.; YUM, I.J.:

Thiol-linked peroxidase activity of human ceruloplasmin. FEBS Lett., 431 (1998), 473-475

KOSTRO, K.; GLIŃSKI, Z.; WÓJCICKA-LENARTOWICZ, K.; KRAKOWSKI, L.:

Acute- phase proteins as indicators of diseases in animals ( in Polish ). Medycyna Wet., 57 (2001) 8, 539-543

KRAKOWSKI, L.; KRZYŻANOWSKI, J.; WRONA, Z.:

Changes of non-specific immunity in piglets in the postnatal period ( in Polish ). Medycyna Wet., 54 (1998) 11, 750-752

KRIŽOVA, H.; MATOUŠEK, V.; MIGDAŁ, W.; NOVAKOVA, J.:

The polymorphism of the transferrin gene ( TF ) in Large White (LW) pigs and its influence on daily gain in piglets ( in Czech ). Sbornik přispěvki z III mezinárodni vědeckè Konference. AGROREGION, (2000), 199-200

LAMPREAVE, F.; RAMON, N.G.; AYENSA, S.M.; HERNANDEZ, M.A.; LORENZO, H.K.; GIL, A.G.; PINEIRO, A.:

Characterization of the acute phase serum protein response in pigs. Electrophoresis, 15 (1994), 672-676

NYSTRÖM, P.E.; JUNEJA, R.K.; JOHANSSON, K.; ANDERSSON-EKLUND, L.; ANDERSSON, K.: Association of the transferrin locus on chromosome 13 with early body weights in pigs. J. Anim. Breed. Genet., 114 (1997), 363-368

OSEK, J.; TRUSZCZYŃSKI, M.: 
Occurrence of fimbriae and enterotoxins in Escherichia coli strains isolated from piglets in Poland. Immunol. Microbiol. Infect. Dis., 15 (1992), 285-292

PRZYTULSKI, T.; KOĆWIN-PODSIADŁY, M.; KLEMKE, A.; PIECH, H.:

Relationship between transferrin phenotypes and ceruloplasmin activity in Large White pigs. Acta Vet. Acad. Scien. Hung., 29 (1981) 4, 389-397

SAENKO, E.L.; SKOROBOGATKO, O.V.; TARASENKO, P.; ROMASHO, V.; ZHURAVETZ, L.; ZADROZNAYA, L.; SENJUK, O.F.; YAROPOLOV, A.I.:

Modulatory effects of ceruloplasmin on lymphocytes, neurophils and monocytes of patients with altered immune status. Immunol. Invest., 23 (1994) 2, 99-114

SZCZEKLIK, E.:

Clinical enzymology ( in Polish ). Issue III. Warszawa PZWL (1974), 227-228

VEDRINE, B.; CIŻOVA-SCHROEFFELOVA, D.; GRANGE, P.; MOURICOUT, M.:

Biochemical and genetic polymorphism transferrin: examination of the three electrophoretic variants. A,B,C. Anim. Genet., 27 (1996) suppl. 2, 39

VORON, F.P.; VESCIPAN, L.P.; SAMOJLENKO, V.T.:

Differences in the iron-biding activity of transferrin variants in pigs (in Russian ). Nauč. Tech. Bjull. Akad. Sel’skochoz. Nauk. Charkov, 11 (1974), 31-37

WIECZOREK, J.:

The effect of excessive supplementation of sulfur on copper metabolism and antioxidant status in young cattle with symptoms of mucosa inflammation ( in Polish ). Medycyna Wet., 59 (2003) 1, 55-57

WIELEBA, E.; PASTERNAK, K.:

Trace elements in antioxidative system ( in Polish ). Medycyna Wet., 57 (2001) 11, 788-791

YOUNG, S.P.; FAHMY, M.; GOLDING, S.:

Ceruloplasmin, transferrin and apotransferrin facilitate iron release from human liver cells. FEBS Lett., 411 (1997), 93-96

ZAGULSKI, T.:

Metabolism of ferrum ions and the defence against infections ( in Polish ). Prz. hod., 12 (1992), 20-23

ZDUŃCZYK, E.; BAKUŁA, T.; PRZAŁA, F.; GAJĘCKI, M.:

The influence of feeding pigs with hydrochloric acid acidified fodder on their health state and iron and copper metabolism under conditions of an industrial fattening unit ( in Polish ). Acta Acad. Agricult. Tech. Olst. Veterinaria, 21 (1993), 175-186

ŻYCZKO, K.; ŻYCZKO, G.M.:

Relationship between transferrin and ceruloplasmin polymorphism and the frequency of diarrhoea in piglets. Arch. Tierz., Dummerstorf, 42 (1999), 175-182

ŻYCZKO, K.; ŻYCZKO, G.M.:

Effect of transferrin ( TfF) polymorphism on the activity of ceruloplasmin ( CP ) content of iron and copper in the blood serum of sows during lactation and litter size ( in Polish ) Biul. Nauk. UWM, 7 (2000), 307-313

ŻYCZKO, K.; ŻYCZKO, G.M.:

Effects of transferrin and ceruloplasmin on the resistance of suckling piglets to Escherichia coli strains causing diarrhea ( in Polish ). Medycyna Wet., 61 (2005) 4, 426-429

Received: 2006-01-27

Accepted: 2006-06-21

Corresponding Author

Dr. habil. KRYSTYNA ŻYCZKO

University of Warmia and Mazury

Faculty of Animal Bioengineering

Department of Animal Genetics

Oczapowskiego 5

10-957 OLSZTYN, POLAND

E-Mail: kgz@uwm.edu.pl 